\title{
OVERWINTERING SURVIVAL OF THE SEVEN-SPOT LADYBUG (COCCINELLA SEPTEMPUNCTATA) IN EDMONTON
}

SHELLEY M. RYAN 9032150 Street, Edmonton, AB T5R 1 E9 and JOHN H. ACORN Department of Renewable Resources, University of Alberta, Edmonton, $\mathrm{AB}$ T6G $2 \mathrm{H} 1$

\section{Introduction}

Ladybugs are beetles belonging to the family Coccinellidae, a family of over 5200 species worldwide. ${ }^{4}$ They are represented by approximately 64 species in Alberta where they are widespread in a variety of habitats, from prairie sand dunes, to the alpine, to peatlands and marshes. ${ }^{1}$ Not all are red or orange with black spots, and it is the larger and more colourful members of the family, in the tribe Coccinellini, that we generally think of when we think of "ladybugs. "Some entomologists prefer the common name "ladybird beetles" to "ladybug" since it is a more accurate term, but here in Alberta the use of "ladybug" is almost universal, so that is the name we prefer.

The purpose of this study was to experimentally examine the over winter survival of hibernating seven-spot ladybugs (Coccinella septempunctata), an introduced species native to Europe. This species has become abundant and widespread in North America over the past 40 or so years, but the reasons for this have not been well studied.

Ladybugs have historically been released to control pests in greenhouses, orchards and croplands. ${ }^{3}$ C. septempunctata was the most commonly released species in the $1950^{1} \mathrm{~s}$ and $1970^{1} \mathrm{~s}$ because of its ability to adapt to a variety of habitats and alternative food sources. ${ }^{3}$ It is suspected that the seven-spot ladybug has spread on its own from its original points of introduction on the east coast of the United States, to eventually establish populations in a variety of habitats throughout Alberta. Gordon (1985) reported an isolated population in the southwester corner of Alberta, and since then there has been a noticeable increase in C.septempunctata ${ }^{1} s$ numbers. Of the 2163 ladybugs identified in various regions of Alberta by the authors in 1995-1998 (but not counting those used in the following studies), 1855 $(86 \%) \quad$ were seven-spots. Simultaneously, some species native to Alberta (notably Coccinella transversoguttata, the transverse ladybug, and C. novemnotata, the ninespot ladybug) have apparently become less common than they once were, but no studies of this major ecological change have been published. However, similar effects were documented in South Dakota, where the arrival of the sevenspot coincided with a reduction in the abundance of C.transversoguttata, and the two-spot ladybug, Adalia bipunctata (Elliot et al. 1996). ${ }^{2}$ Thus, there is reason, 
to believe that the seven-spot has had a negative effect on the biodiversity of native ladybugs in Alberta, although the mechanism involved is unknown.

High overwinter survival may play a role in the Seven-spot's success in North America. In Great Britain, many species of coccinellids aggregate at overwintering sites in large numbers (Majerus, 1994), and we have observed this in Alberta as well. Survival of hibernating ladybugs is dependent on many factors, including 1) nutritional state before hibernation, 2) temperature and humidity during hibernation, 3) suitability of habitatsite,4) diseases, and 5) predators. Ladybugs are affected by viral and fungal pathogens in Europe, where mortality caused by a pathogenic fungus (Beauveria sp.) is common. ${ }^{7}$ Hibernating ladybugs may also be vulnerable to attack by ants, spiders, carabid ground beetles, mites, and nematodes.

\section{The Studies}

\section{Observations of Naturally Hibernating Ladybugs}

From October of 1996 to April 1997, seven-spot ladybugs were collected from a hibernation site at the Opal Natural Area, $10 \mathrm{~km}$ northeast of Opal, Alberta. The site is in a boreal mixedwood forest, on stabilized sand dune soils, and the vegetation at the site is dominated by jack pine (Pinus banksiana) with a ground cover of reindeer lichen (Cladina mitis). Nearby, aspen parkland vegetation, characterized by aspen poplar (Populus tremuloides), white spruce (Picea glauca) and prickly wild rose (Rosa acicularis) is abundant. As well, there is a marsh area adjacent to the reserve to the west.

Prior to hibernation, common predators at the site included ants and

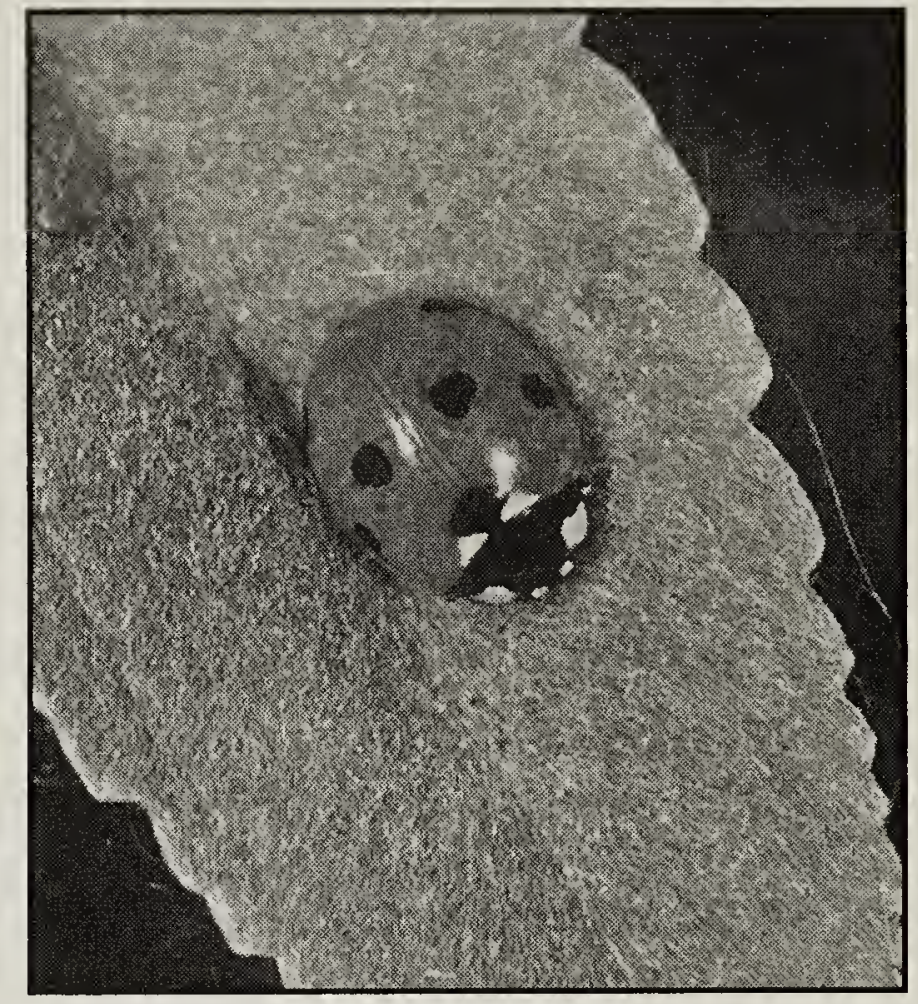

Seven-spot Ladybug (Cocinella septempunctata, Edm, AB.

John H. Acorn

spiders. Potential ladybug prey, in the form of aphids and small dipteran flies, were abundant at the site, and ladybugs were observed eating both types of prey before hibernation. Although feeding does not occur during the winter months, it is important that ladybugs feed constantly prior to hibernating. ${ }^{7}$

Along with nutrition, appropriate moisture levels are important for overwintering survival-too much can cause drowning, too little can cause desiccation. During mid winter, the reindeer lichen was supple and moist under the snow, while in mid summer it is often dry and crumbling. Thus, the microhabitat gave the impression of having abundant but not excessive moisture. Reindeer lichen also continues to respire under the snow, possibly increasing oxygen levels and reducing the suitability of the site for Beauveria fungus, which thrives in anaerobic conditions. ${ }^{6}$

In April, only four ladybugs were found dead at the site. Of those, 2 were found on decayed leaf litter and soil, and both 
showed signs of fungal growth. The other two were dissected, whereupon adult and larval mites were found internally. Unfortunately, these mite specimens were misplaced, and further identification was not possible. One adult mite was found within the abdominal wall of one of the sevenspots, and two larvae were found feeding among the ovaries of the other seven-spot. It is not possible to know if they killed the ladybugs or were attracted to the carcasses.

\section{Experimental Overwintering of Seven-spot Ladybugs}

On October 15, 1996, over 150 sevenspot ladybugs were collected at the Opal Natural Area in less than 20 minutes, using an aspirator and a sweep net. They were then put into $10 \mathrm{~cm} \times 10 \mathrm{~cm} \times 13$ $\mathrm{cm}$ wooden boxes with $10 \mathrm{~cm} \times 10 \mathrm{~cm}$ pieces of screening stapled to the tops, preventing any escapes. The wood used for the boxes was $2 \mathrm{~cm}$ thick. Five boxes were lined with18-19grams of leaf litter (LL), and one was lined with 52 grams of reindeer lichen (DL). All of the boxes were stocked with 20 seven-spot ladybugs except for one of the LL boxes, which received 50 . On October 17 the boxes were placed into the ground in a suburban flower garden in Edmonton, such that the tops of the boxes were flush with the soil surface. The area was then covered with a thin layer of leaf litter and left until April 16,1997. In January and February of 1997 , thermistor probes attached to a Lakewood Systems model $\mathrm{mL}-16 \mathrm{E}$ Ultra-logger monitored daily maximum and minimum air temperature, soil surface temperature and temperature $5 \mathrm{~cm}$ below thes oil surface where the ladybugs would be present.

On April 16, 1997, the ladybugs were taken out of the boxes and surviving individuals became active within five minutes of reaching room temperature.
These ladybugs were kept alive on liver cat food until outside conditions permitted their release. Dead ladybugs were dissected and observed under a stereo microscope for possible causes of mortality.

The survival rate of seven-spots at the experimental site was very high at $97 \%$. Only 5 of the 152 ladybugs died, 4 of which showed signs of fungal infection. Fungal spores were easily observed on the exterior of the beetles, and there was a thickened cheesy mass internally, matching Hodek's (1973) description of Beauveria. This fungus is found naturally in soil and compost material. The fifth ladybug was desiccated internally, and the cause of its death is unknown. A metre-deep blanket of snow insulated the ladybugs from cold and desiccation in both locations. Although the temperature dropped to $30 f \mathrm{C}$ several times during January the temperature at the soil surface and just below the soil remained between $5^{\circ} \mathrm{C}$ to- $9^{\circ} \mathrm{C}$, as recorded by the data logger. Presumably, we witnessed nearly ideal conditions for overwintering, compared to the humid and wet winters of Great Britain, where $50 \%$ of ladybugs can be infected with Beauveria. ${ }^{7}$

\section{Other Potential Reasons for the Seven-spots ${ }^{1}$ Success}

During this study, a number of ladybugs were kept in small terraria for observation. Although these observations were not carefully quantified, they do point to a few areas where further research might prove fruitful.

Captive seven-spot and transverse ladybugs appeared to possess roughly equivalent fecundity, measured by the numbers of eggs they laid in a 24-hour period. Female seven-spots laid between 12-50 eggs, while female transverse ladybugs laid between 15-49 eggs. 


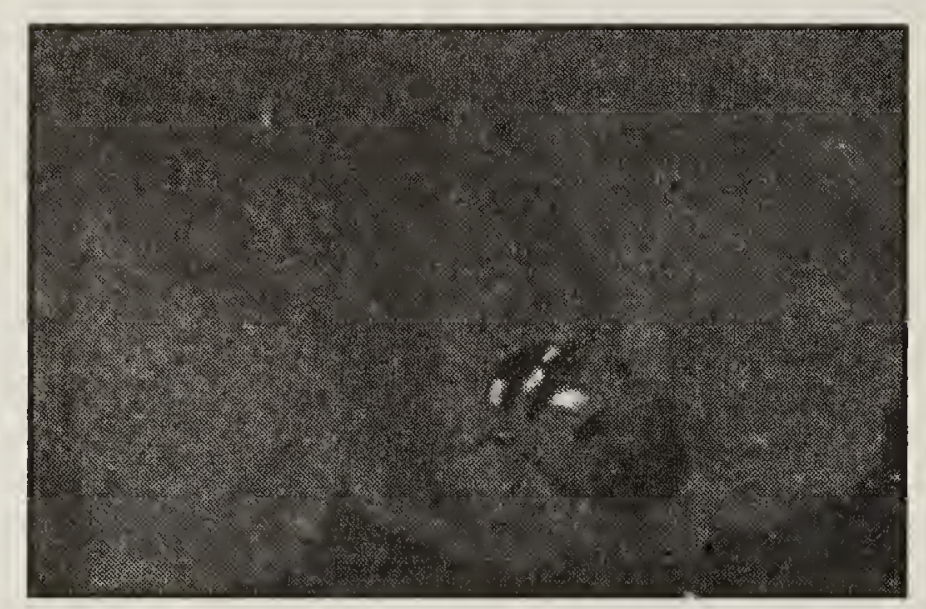

Transvese Ladybug (Coccinella transversoguttata) Edmonton, $A B$

John Acorn

Adults of both species readily ate both their own eggs and those of the other species. While foraging, however, the seven-spots appeared much more active and aggressive, compared to the slow, passive transverse ladybugs. Whether any of these factors are important to the interactions between the two species remains to be demonstrated.

\section{Conclusions}

In general, it seems that the sevenspot ladybug is very much at home here in Alberta. It enjoys much higher overwinter survival than in its British home land, and may also be a more active and aggressive beetle than its Canadian relatives as well. It has certainly come to dominate the ladybug fauna here, but the reasons for its success are still very poorly known.

\section{Acknowledgements}

This study was completed by Shelley Ryan as part of the requirements for the Biological Sciences program at the Northern Alberta Institute of Technology. Robin Leech served as Shelley's project supervisor, while John Acorn acted as an informal advisor. Shelley was assisted in the field by Cody Hovind, Nicole Ryan, and Aaron Ryan. A review of the manuscript by Cedric Gillott substantially improved the quality of this paper. Thanks are also due to Rod Feland, Larry Macdonald, Dwayne Dorland, the Edmonton Natural History Club, and the students of James Gibbons Elementary School. Final preparation of this report was completed by John Acorn, when family commitments prevented Shelley from doing so herself.

\section{Literature Cited}

1. BELICEK, J. 1976. Coccinellidae of Western Canada and Alaska with analyses of the transmontane zoogeographic relationships between the fauna of British Columbia and Alberta (Insecta: Coleoptera: Coccinellidae). Quaestiones Entomologicae 12: 283409.

2. ELLIOT, N. C., R. W. KIECKHEFER, and W. C. KAUFMAN. 1996. Effects of an invading coccinellid on native coccinellids in an agricultural landscape. Oecologia (Berl.) 105: 537-544.

3.GORDON, R. D. 1985. The Coccinellidae (Coleoptera) of America North of Mexico. New York Entomol. Soc. 93: 1912.

4. HAWKESWOOD, T. J. 1987. Beetles of Australia. Angus \& Robertson, North Ryde, NSW. 248 pp.

5. HODEK, I. 1973. Biology of Coccinellidae. Academia Prague \& Dr. W.Junk. The Hague. 260 pp.

6. JOHNSON D., L. KERSHAW, A. MACKINNON, J. POJAR. 1995. Plants of the Western Boreal Forest and Aspen Parkland. Lone Pine Publishing and the Canadian Forest Service, Edmonton. $392 \mathrm{pp}$.

7. MAJERUS, M. E. N. 1994. Ladybirds. Harper Collins Publishers, London.367 pp. 